Relations industrielles

Industrial Relations

\title{
Mishel, Lawrence, Jared Bernstein and John Schmitt, The State of Working America, 1998-99
}

\section{Laura Dresser}

Volume 54, numéro 4, 1999

URI : https://id.erudit.org/iderudit/051280ar

DOI : https://doi.org/10.7202/051280ar

Aller au sommaire du numéro

Éditeur(s)

Département des relations industrielles de l'Université Laval

ISSN

0034-379X (imprimé)

1703-8138 (numérique)

Découvrir la revue

Citer ce compte rendu

Dresser, L. (1999). Compte rendu de [Mishel, Lawrence, Jared Bernstein and John Schmitt, The State of Working America, 1998-99]. Relations industrielles / Industrial Relations, 54(4), 828-830. https://doi.org/10.7202/051280ar

Tous droits réservés (C Département des relations industrielles de l'Université Laval, 1999
Ce document est protégé par la loi sur le droit d'auteur. L'utilisation des services d'Érudit (y compris la reproduction) est assujettie à sa politique d'utilisation que vous pouvez consulter en ligne.

https://apropos.erudit.org/fr/usagers/politique-dutilisation/ 
steel industry. The Chrysler plant makes small trucks - a booming market in North America. The GM plan makes Cavalier and Chevy models for North and South America and GM is making huge efforts to regain its traditional market share.

However, all three plants have some common features that could be problems in the future. All three factories heavily depend on exports, primarily to the USA. Workers and supervisors in the Mexican plants are fully aware that they are part of the new globalized economy. Their prospects are inherently linked to the prospects of the American economy and they all know it.

The author emphasizes that the future success of these factories cannot separated from the future prospects for
Mexican society as a whole. At the time of the study, inflation was running at $15 \%$. Some 700,000 new jobs had been created, but a million are required to contain the demographic explosion in Mexican society. Otherwise, underemployment and impoverishment will be the inevitable result. High crime rates and conflict in the labour movement are also well known.

The previous stability in Mexican society rested on a balance between political and public actors. Confidence and trust in the traditional power centers have now been lost. We do not know how this will work out for the system. The author expresses hope and confidence that they can work it out. So should we all.

PETER WARRIAN

University of Toronto

The State of Working America, 1998-99

Lawrence MISHEL, Jared BERNSTEIN, and John SCHMITT, Ithaca, N.Y.: Cornell University Press, 1999, 480 p., ISBN 0-8014-3613-3 (cloth), ISBN 0-8014-8582-7 (paper).

Unprecedented growth! Rocketing stock prices! Unbelievably low unemployment! In recent years, the US economy has inspired not only excessive superlatives, but also envy throughout the world. The rush to "Americanize" labour market structure is on and policy makers and economists extol the virtues of liberalized markets, weak unions, low standards on training and wages, reductions in the welfare state, and empowered capital. But before you run out to follow the trend, The State of Working America 1998-99 should be required reading.

Since 1988, this report has been prepared biennially and released by the Economic Policy Institute, a Washington DC think-tank. With its abundant statistics, detailed analyses, and intemational comparisons, The State of Working America 1998-99 provides a more comprehensive picture than any other resource of what is really going on in the United States economy, who has gained from it, and why it is happening.

The book can be used simply as a statistical almanac - it provides the numbers on wages, living standards, and inequality. Placing the US miracle in a historical context, and looking carefully at who is winning and who is losing in recent years, the authors paint a much more complete picture of the state of working families in the US. Take, for example, the fact that the years of boom have produced only $0.1 \%$ increase in family income (p.40). And while it is finally widely accepted that income inequality grew dramatically over the 1980 's in the States (and the authors deserve credit for pushing the evidence on that), The State of Working America shows dramatic growth in income inequality extended into the 1990s. The evidence on hours of work per family presents an equally compelling story. From 1989 to 1996, the median-income, married cou- 
ple family increased their hours of paid work by 3.8 percent; that's more than three weeks of full-time work added. The income reward for all that extra work was only $\$ 607$ or 1.1 percent (p. 18).

Readers should be sure to look to the text in addition to the numerous tables and charts. In the text, the authors systematically explore prevailing explanations of policy makers and economists about the source of US strength and prevailing excuses for why wage inequality has increased so dramatically over the last two decades. For example, they succinctly debunk the popular "technology" explanation for increasing wage inequality. The explanation, that technology has transformed the wage structure rewarding those with college degrees and leaving the "unskilled" behind, is popular. But evidence doesn't line up. As the authors point out, if technology was advancing rapidly enough to fundamentally alter the wage structure, there should be some evidence of a boom in productivity growth creditable to the same source. Moreover, the wage trends and the timing of those trends do not line up with the simple story of skill biased technological change. As an alternative to this explanation, the authors point to the decline in labour market institutions - erosion of the real value of the minimum wage and deunionization - which together account for more than one-third of the increasing wage inequality.

Finally, in its last chapter, which may be of most interest to Canadian readers, the authors provide a thorough international comparison of US experience in the last two decades. Reviewing evidence on productivity, per capita income, hours of work, poverty rates, and mobility, among others, the authors compare US experience to other OECD countries. Though high poverty and inequality in the US is generally acknowledged, the standard argument is that high mobility in the US and abundant opportunity makes up for high poverty and inequality. Economic dynamism generates jobs rapidly, and technical innovation pushes productivity further ahead. International comparisons show, however, that the US doesn't really measure up to this popular conception. Compared with other nations, the US produces higher inequality and poverty rates (both before and after taxes and transfers) than almost any other developed nation and the US disadvantage is growing. But low-wage workers in the US are not protected by high mobility; in fact, low-wage workers and poor families in the US are less likely to move out of poverty than those in most OECD nations are. Moreover, the authors point out that US job generation is no better than that of several other OECD countries and neither is productivity growth.

The most important international evidence comes in a comparison of patterns of unemployment. Standard analysis credits the lack of labour market regulation in the US, especially at the bottom of the labour market where unions, minimum wages, and provisions to prop up the wage floor, for low unemployment rates. The authors point out that, if this were true, the ratio of unemployment between high and low-skilled workers should be relatively smaller in the US, where wages can fall to increase employment for low-skilled workers and relatively higher for other OECD countries, where wages standards may force some at the bottom of the labour market out of work. In fact, however, that ratio is substantially higher in the US. High school graduates are 1.9 times as likely to be unemployed as college graduates in the US; in Canada, unemployment for high school graduates is only slightly more likely than for college graduates (the ratio is 1.2).

For awhile, in the late 1980s and early 1990s, policy makers and establishment economists argued that inequality was not on the rise in the US. The Economic Policy Institute consistently documented and disseminated the information on the scale of the shift. Now everyone admits 
it happened, though the debate on why and who gained still continues. That sort of analysis and focus on the broad picture of living standards in the US is what makes this book so valuable. The authors systematically and carefully document both the good and the bad in the economy and keeps its eye on the big economic issues while arguing with solid statistics. But perhaps one of the most useful features of the book is simply its accessibility. It is not written only for economists and it doesn't overpower with econometric technique when a simple table will make the point.

Throughout The State of Working America, it is clear that the authors' per- spective sits to the left of the economic establishment in the US, but in writing such an accessible book, they encourage increased economic literacy among people from across the political spectrum. Additionally, their international comparisons may help inform debate and policy making among those OECD countries that are looking to the US model for solutions to their labour market problems.

LAURA DRESSER

Center on Wisconsin Strategy University of Wisconsin-Madison

\section{Les politiques de l'emploi en Europe et aux États-Unis}

sous la direction de Jean-Claude BARBIER et Jérôme GAuTIÉ, Paris : Presses universitaires de France, 1998, 435 p., ISBN 2-11-088609-9.

La lecture de ce livre est fortement recommandée pour quiconque s'intéresse de près ou de loin aux politiques de l'emploi. Il se divise en deux parties. On y retrouve d'abord une description des principaux points qui caractérisent les politiques de l'emploi dans plusieurs pays européens parmi lesquels on retrouve le Royaume-Uni, la France, la République fédérale d'Allemagne, la Suède, le Danemark, les Pays-Bas ainsi que les politiques d'emploi américaines. Ensuite, le livre présente des analyses transversales effectuées par différents auteurs qui évaluent, notamment, les impacts de ces politiques dans une perspective microéconomique et macro-économique et qui se penchent également sur des questions d'intérêt général comme le partage du travail, l'économie sociale et la recherche d'une politique européenne de l'emploi. Le livre conclut en s'interrogeant, à partir des comparaisons de politiques nationales de l'emploi, sur le cadre d'analyse le plus approprié pour effectuer de telles comparaisons ainsi que sur l'avenir de telles politiques.

Rappelons que les politiques de l'emploi désignent généralement l'ensemble des interventions prises dans le cadre des politiques économique et sociale d'un pays pour influer sur le niveau de l'emploi et du chômage. Ces interventions peuvent être d'ordre budgétaire, monétaire, fiscal, réglementaire ou encore elles peuvent être plus ciblées et concernent généralement les politiques du marché du travail qui influent directement sur l'offre et la demande de travail ainsi que sur l'ajustement entre les deux.

La lecture de l'ouvrage conduit au constat suivant, à savoir que pour plusieurs pays, la politique de l'emploi n'en est qu'à ses balbutiements. Au contraire, la politique du marché du travail est développée et concrète dans tous les pays étudiés. À cet effet, il est intéressant de constater que la réduction et l'aménagement du temps de travail ont joué un rôle central dans le cadre de la politique de l'emploi de certains pays parmi lesquels on retrouve la République fédérale d'Allemagne, la France, les Pays-Bas. Dans ces pays, toutefois, même si la durée hebdomadaire légale a diminué depuis 20 ans, la forte baisse des heures annuelles moyennes rémunérées s'expliquerait en 